\title{
Financing of Dengue Hemorrhagic Fever Control Program in Banda Aceh City
}

\author{
Ellia Nufara*, Ali Ghufron Mukti, Tri Baskoro T. Satoto Mail
}

*Correspondent Author: nufarae@yahoo.com

*Doctoral Program, Faculty of Medicine, Universitas Gadjah Mada, Yogyakarta, Indonesia

\begin{tabular}{l}
\hline I N D E X I N G \\
\hline Keywords: \\
Financing; \\
DHF Control Program; \\
Case-Control Study;
\end{tabular}

Kata Kunci:

Pembiayaan;

Program Pengendalian

$D B D$;

Studi Kasus-Kontrol;

\begin{abstract}
A B S T R A C T
From January to June 2017, the number of DHF cases in Banda Aceh City reached 216 cases with the incidence Rate of $89.5 \%$. To suppress the increase in the cases, the Health Office of Banda Aceh and its staff has conducted control activities, but the number of DHF cases is difficult to reduce. It is therefore necessary to conduct this study to assess the relationship between the availability of DHF control programs and the number of DHF cases in Banda Aceh City. Methods: This observational was done using a case-control study design. The number of samples was 76 cases in four selected health centers with a case-control ratio of 1:1. For data collection, it was conducted in July until August 2017. Results: The results show that the reduction in funding of DHF disease control programs was associated with an increase in the number of DHF cases in Banda Aceh City $(\mathrm{p}=$ $0.005, \mathrm{OR}=2.49$ at $95 \% \mathrm{CI} ; 1.23-5.06$ ). Conclusion: Inadequate financing can increase the number of DHF cases in Banda Aceh City.
\end{abstract}

Dari Januari hingga Juni 2017, jumlah kasus demam berdarah di Banda Aceh mencapai 216 kasus dengan tingkat kejadian 89,5\%. Untuk mengurangi peningkatan kasus, Dinas Kesehatan Banda Aceh dan stafnya telah melakukan tindakan pengendalian, tetapi jumlah kasus DBD sulit untuk dikurangi. Oleh karena itu perlu dilakukan penelitian ini untuk menilai hubungan antara ketersediaan program pengendalian DBD dan jumlah kasus demam berdarah di Kota Banda Aceh. Metode: Penelitian ini dilakukan menggunakan desain studi kasus-kontrol. Jumlah sampel adalah 76 kasus di empat puskesmas terpilih dengan rasio 1: 1 kasus kontrol. Untuk pengumpulan data, dilakukan dari Juli hingga Agustus 2017. Hasil: Hasilnya menunjukkan bahwa pengurangan program pengendalian penyakit DBD terkait dengan meningkatnya jumlah kasus demam berdarah di Kota Banda Aceh $p=$ 0,005, OR $=2,49$ pada 95\% CI ; 1.23-5.06). Kesimpulan: Pembiayaan yang tidak memadai dapat meningkatkan jumlah kasus demam berdarah di Kota Banda Aceh.

(C) 2018 JMMR. All rights reserved

\section{INTRODUCTION}

An estimated 2.5 billion people worldwide are at risk of developing Hemorrhagic Fever Dengue (DHF) so that the disease is categorized as one of the world's most contagious infectious diseases. 1 Every year, an estimated 50 million DHF new cases are found with an average mortality rate of $2.5 \%$. For that, efforts in the prevention of this disease are needed.

Tackling DHF disease is closely linked to achieving the target of Sustainable Development Goals (SGDs) whose goal is, among others, to combat HIV/AIDS, malaria and other infectious diseases, including DHF. As a contagious and deadly disease, DHF needs attention and priority for its prevention and eradication. ${ }^{2}$ As a tropical country, Indonesia is known as an endemic area for DHF disease. Geographical conditions, temperature, environmental conditions and other natural factors in the country support the development of this disease. When its outbreak was first discovered in Surabaya in 1968, 58 cases were reported with 24 people who died with a Case Fatality Rate (CFR) of $50 \%$. 3 The area of DHF disease in the country is increasingly widespread and by mid-2013 the number of cases reached 48,905 people with 376 deaths. ${ }^{4}$ Increase in the cases continued and until 2016 the reported cases were 201,885 , with an Incidence Rate (IR) of 77.96/100,000 people accompanied by 1,585 deaths with CFR of $0.79 \%{ }^{5}$ DHF distribution area in the country has also impacted Banda Aceh City, Aceh Province. The administration of Banda Aceh City consists of 9 subdistricts, 11 Public Health Centers (PHCs) and 90 villages that are mostly endemic areas of DHF.6 The number of DHF cases in Banda Aceh. 


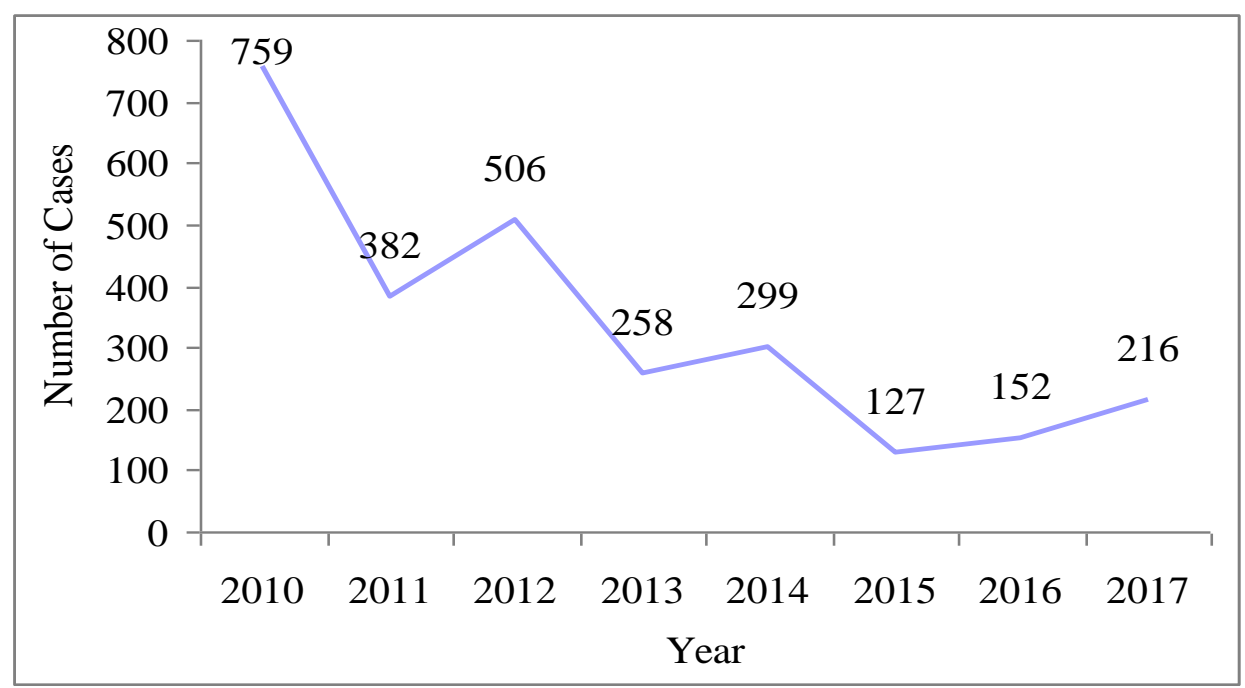

Figure 1. Number of DHF Cases in Banda Aceh City from 2009 to June 2017

In 2010, 759 DHF cases were detected in this city with 9 deaths. Although until 2017 the number of DHF cases was lower than that in 2010 , the case had always been up and down from year to year. The number however tended to increase again since 2015 . The increase in cases that occurred in 2016 recorded 152 people with IR of $61 \%$ and CFR of $0 \%$, when compared to the previous year (2015) with the number of cases as many as 127 people. In
2017 in the first semester (January-June) the number of cases reached 216 people with one death (IR of $89.5 \%$ and CFR of $0.48 \%$ ). 6 In Figure 2 we can see the number of DHF cases at each PHC in the first half of 2017.6 The highest, medium, and lowest number of cases occurred in the working area of Baiturrahman (35 cases), Lampulo (18 cases) and Meuraxa (8 cases) PHC, respectively.

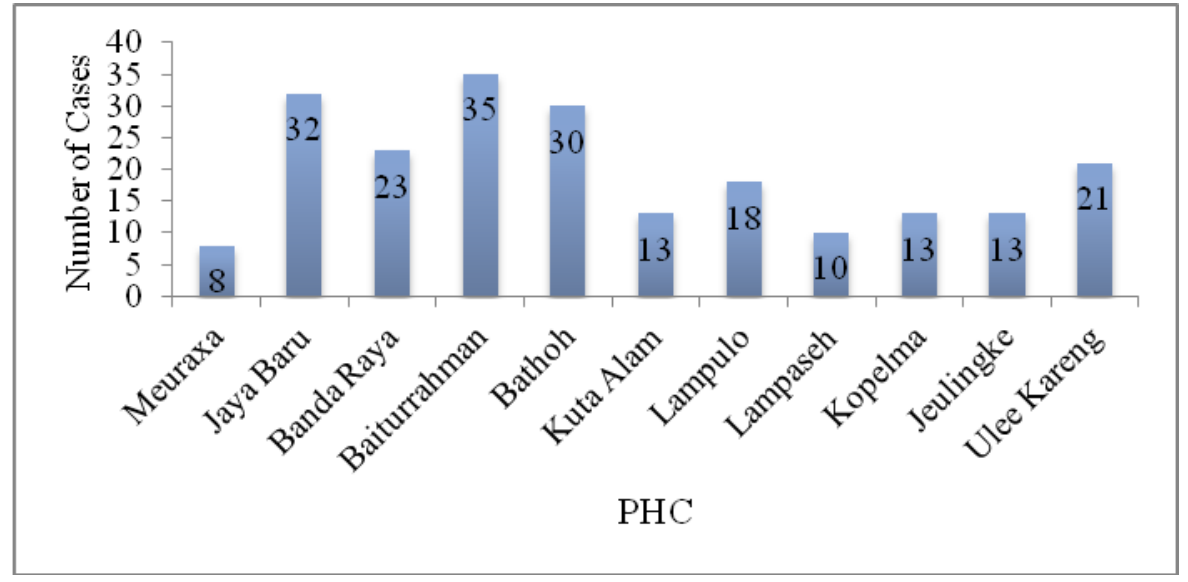

Figure 2. Number of DHF Cases in Each PHC in Banda Aceh City from January to June 2017

Since reducing morbidity and suppressing mortality due to DHF disease is not easy, there should be an inseparable link between local government policies and partnerships with donors to community participation. In the effort to control this disease, the Banda Aceh City Health Office had funding from the District/City Budget with the amount of fund that can be seen in Table 1 (2014-2017). The source of this fund showed that there had been a decrease from year to year. Compared to the previous year, the amount of fund in 2017 reduced to IDR (Indonesian Rupiah) $275,880,800$ of the proposed amount of IDR $350,000,000^{6}$. 
Table 1. Amount of Fund for DHF Control Program in Banda Aceh Health Office in 2014 - 2017

\begin{tabular}{llc}
\hline No & Year & Amount (Rupiah) \\
\hline 1 & 2014 & 473.821 .500 \\
2 & 2015 & 343.646 .200 \\
3 & 2016 & 326.371 .200 \\
4 & 2017 & 275.880 .800 \\
& Total & $\mathbf{1 . 4 1 9 . 7 1 9 . 7 0 0}$
\end{tabular}

Source: Banda Aceh Health Office Year 2017

The amount of fund is not sufficient to program activities that must be done. This condition of course requires a policy commitment from the local government so that the budget for the DHF disease control program can be improved. Thus, program managers can be more innovative in planning program activities. The activities that have been done can be seen in the following table:

Table 2. Amount of Fund in Each Activity of DHF Control Program in Banda Aceh City in 2017

\begin{tabular}{llcc}
\hline No & Activity & Category & Amount (Rupiah) \\
\hline 1. & Fogging focus & case & $471.500 /$ case/cycle \\
2. & Case tracking to hospital & 2 time monthly & $50.000 /$ person \\
3. & Epidemiological research & case & $50.000 /$ person \\
4. & Abate distribution & $127.5 \mathrm{Kg}$ & 36.450 .000 \\
5. & Mobile dissemination & 50 villages & 5.100 .000 \\
\hline
\end{tabular}

Source: Banda Aceh Health Office Year 2017

Table 2 shows the amount of cost for DHF control program activities in Banda Aceh City in 2017. The most commonly used cost was for fogging focus and each case cost IDR 471,500 per cycle, while fogging should be done in two cycles. To conduct each time case tracking to the hospital twice a month involved 4 health workers with honorarium of IDR 50,000 / person for six months. Abate of $127.5 \mathrm{Kg}$ with the price of IDR. $36.450 .000 \mathrm{had}$ to be distributed at $11 \mathrm{PHC}$ areas. Total cost for dissemination services to villages was IDR 5,100,000 for 50 villages out of 90 villages in the administrative area of Banda Aceh City $^{6}$. Therefore, this study was focused on assessing the relationship between the financing of the DHF disease control program and the number of DHF cases found in Banda Aceh City.

\section{RESEARCH METHOD}

This observational research used a case-control study design with four health centers selected as the case analysis unit (Baiturrahman, Lampulo, Meuraxa and Ulee Kareng) using total sampling method. The research was conducted for 2 months from July to August 2017. The cases were patients with a positive diagnosis of DHF recorded at selected health centers in Banda Aceh City from January to June 2017. Clinical diagnosis was determined by the physician at the hospital where the patient was receiving treatment. The controls were those as the neighbor of the cases that did not suffer from the disease under study. The sample size was 152 people, consisting of 76 cases and 76 controls.

The dependent variable was the financing of DHF disease control program and the independent variable was the number of DHF cases found in Banda Aceh City. Data collection was based on case observation, control and financing data in the field and interview by using questionnaire as a structured guideline based on research variables. Data processing was descriptive and bivariate data analysis used Stata.

\section{RESULT AND DISCUSSION}

\section{Case Description}

This research was conducted for 2 (two) months, i.e., July to August 2017 and found 76 cases in the selected working area of PHCs during the period of January to June 2017. The initial data count was 82 cases, but because of the change of residence, the number of cases encountered remained only 76 cases. The distribution of research cases is as follows: 


\section{a. Case Distribution by Age Group}

The number of DHF cases in Banda Aceh City was varied by age group (Fig. 3). Based on age, the group above
15 years and less than one year showed the highest and fewest number of cases $(32$ cases $/ 42,11 \%$ and 2 cases $/ 2.63 \%$, respectively).

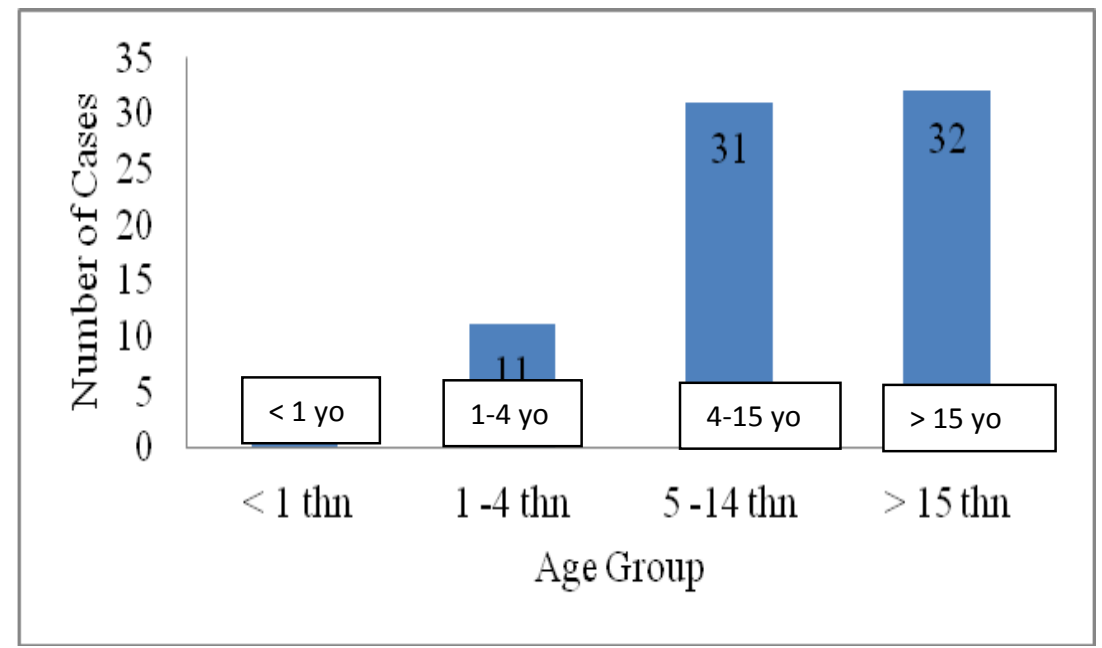

Figure 3. Distribution of DHF Cases by Age Group in Banda Aceh City from January to June 2017

\section{b. Case Distribution by Sex}

Based on sex, DHF cases were more common in male (39 cases $/ 51.32 \%$ ) than in female (37 cases $/ 48.8 \%$ ).

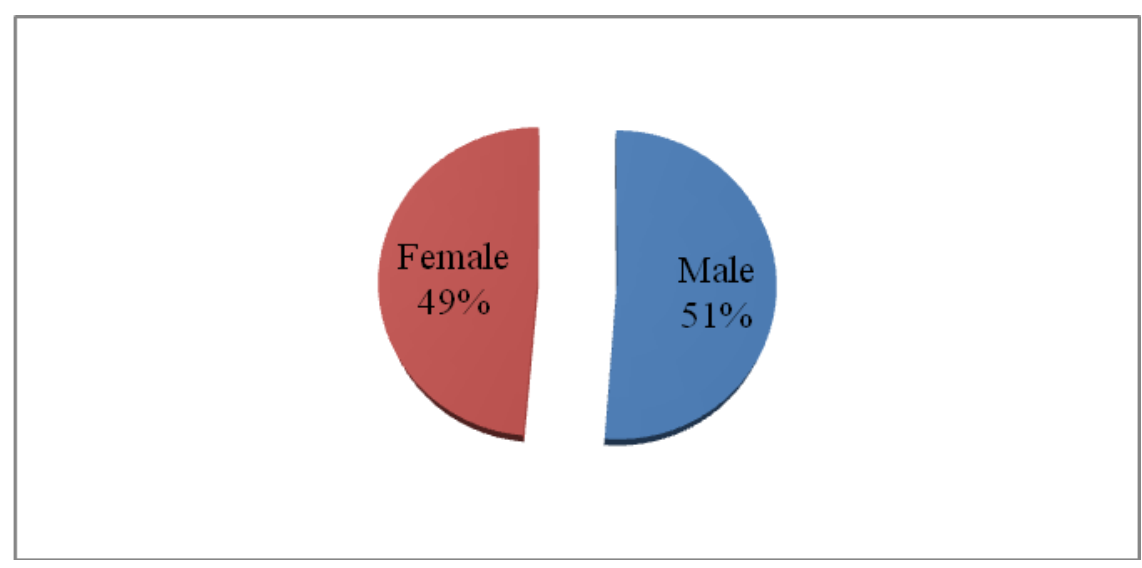

Figure 4. Distribution of DHF Cases by Sex in Banda Aceh City from January to June 2017

\section{c. Case Distribution by Health Center}

Figure 5 shows that DHF cases were more prevalent in residents who lived around the Baiturrahman Health Center area with 31 cases $(40.79 \%)$, followed by Ulee Kareng Health Center (19\%), Lampulo Health Center (18 cases $(23.68 \%)$ and Meuraxa Health Center as many as 8 cases $(10.53 \%)$. Initial data for Baiturrahman and Ulee Kareng Health Center were 35 cases and 21 cases, respectively; however, the number was reduced at the time of the study because of the displaced population. 


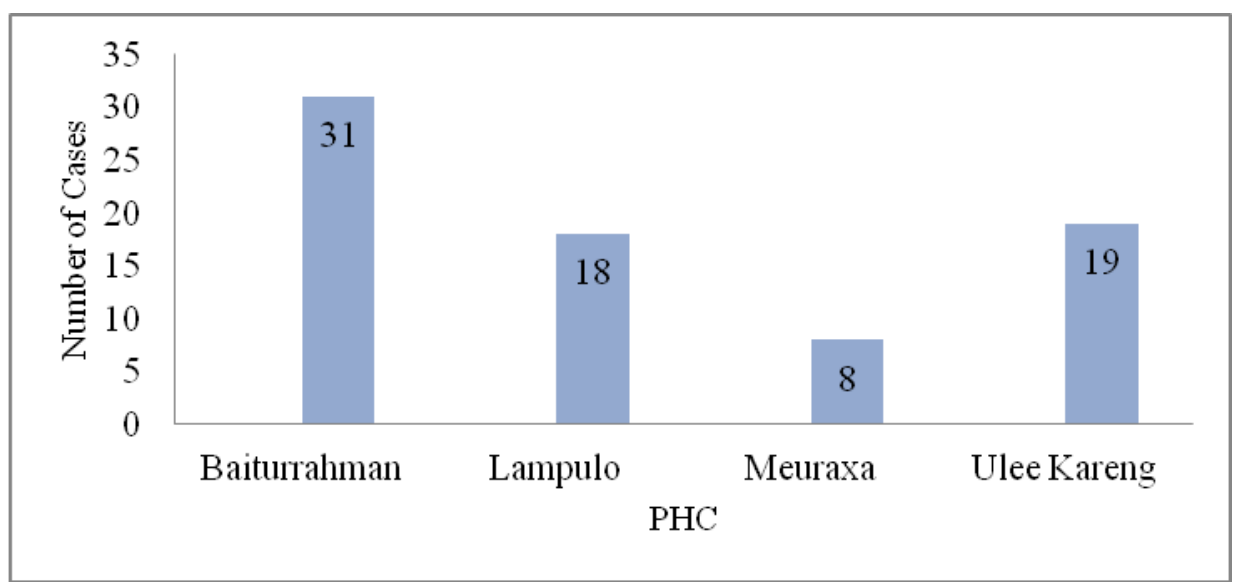

Figure 5. Distribution of DHF Case Based on PHC in Banda Aceh City from January to June 2017

\section{d. Case Distribution by Case Detection Time}

The number of DHF cases based on the detection time in Banda Aceh City can be seen in the following graph:

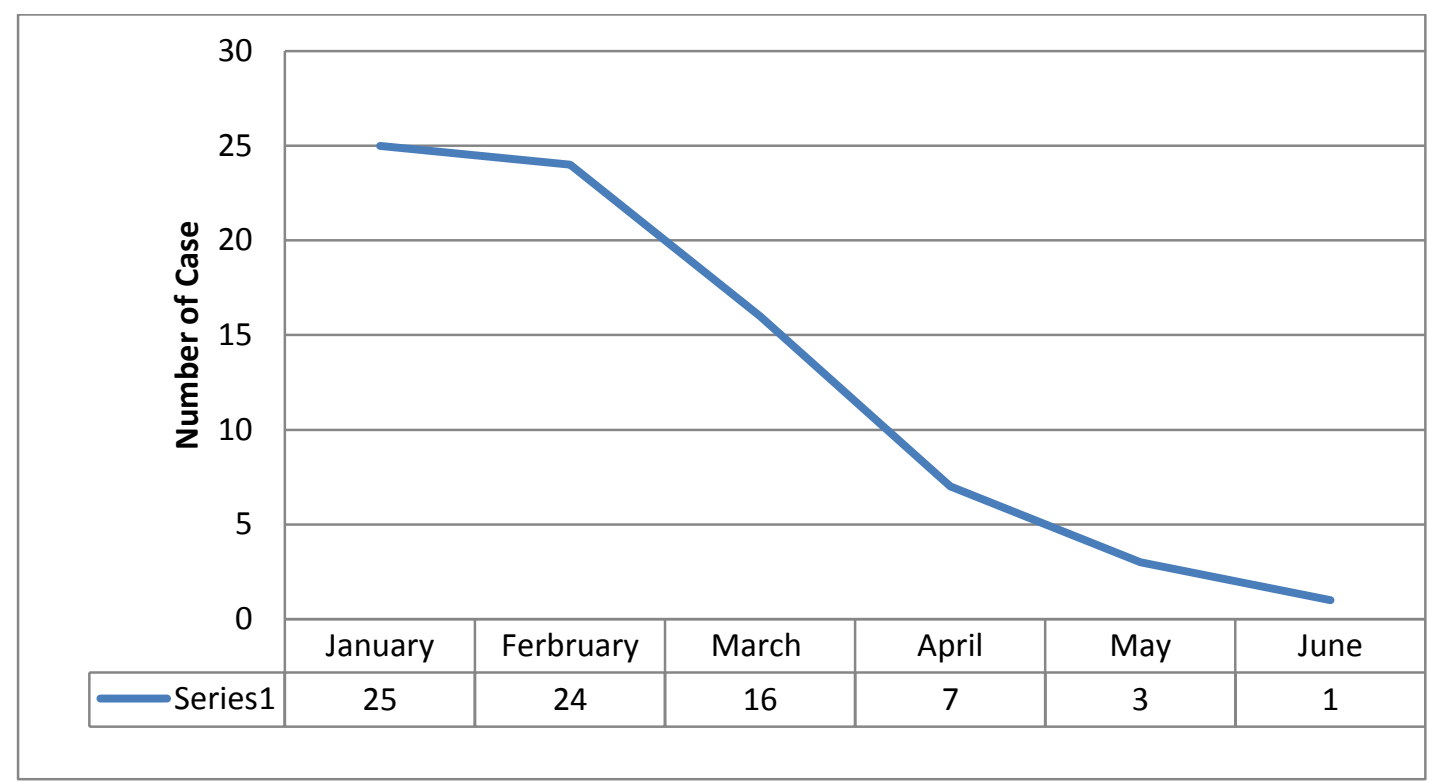

Figure 6. Distribution of DHF Cases Based on Detection Time in Banda Aceh City from January to June 2017

Figure 6 shows that the highest number of cases occurred in January by 25 cases, followed by February by 24 cases and the lowest in June by only one case.

\section{Bivariate Analysis}

The bivariate analysis between the financing of the DHF control program and DHF cases obtained an $\mathrm{X}^{2}$ value of 7.63 and a p-value of 0.005 with (OR of 2.49 at $95 \%$ CI 1.23-5.06), biologically and statistically significance. This means that insufficient DHF program financing was a risk factor associated with DHF incidence.
Inadequate funding for DHF program provided an opportunity to increase the DHF cases by 2.49 times greater than adequate funding. 
Cost Analysis of DHF Program

\section{a. Cost Analysis for Each DHF Case}

Table 3. The Amount of Cost for Each DHF Case in Banda Aceh City from 2014 to 2017

\begin{tabular}{cccc}
\hline Year & Cost (Rupiah) & Cases & Cost/Case (Rupiah) \\
\hline 2014 & $473,821,500$ & 299 & $1,584,687.29$ \\
2015 & $343,646,200$ & 127 & $2,705,875.59$ \\
2016 & $326,371,200$ & 152 & $2,147,178.95$ \\
2017 & $275,880,800$ & 216 & $1,277,225.93$ \\
\hline
\end{tabular}

Source: Banda Aceh City Health Office in 2017

Table 3 shows that cost for the DHF disease control program continued to decrease from 2014 to 2017. In 20152017 there was a relationship between reducing program cost and increasing the number of DHF cases. The number of cases increased to 216 in the first half of 2017 from January to June.

\section{b. Cost Analysis for Each Selected Health Center}

The amount of cost provided by the Banda Aceh City Health Office at each health center was in accordance with the number of cases as most of the fund was for curative programs (Table 4). The greatest amount of money was provided for Baiturrahman Health Center amounting to IDR $39,630,500$ and the lowest cost was given to Meuraxa Health Center for IDR 12,819,000. The cost was adjusted to the number of cases in the respective health center areas and in accordance with the preliminary data: Baiturrahman ( 35 cases), Lampulo (18 cases), Meuraxa ( 8 cases) and Ulee Kareng (21 cases).

Table 4. Amount of Cost from Banda Aceh City Health Office for Each Selected PHC in 2017

\begin{tabular}{clcccr}
\hline No & \multicolumn{1}{c}{ PHC } & $\begin{array}{c}\text { Fogging Cost } \\
\text { (Rupiah) }\end{array}$ & $\begin{array}{c}\text { Epid. Research cost } \\
\text { (Rupiah) }\end{array}$ & $\begin{array}{c}\text { Abate Cost } \\
\text { (Rupiah) }\end{array}$ & $\begin{array}{c}\text { Total (Rupiah) } \\
\text { (Ruhn }\end{array}$ \\
\hline 1. & Baiturrahman & $33,005,500$ & $1,750,000$ & $4,875,000$ & $39,630,500$ \\
2. & Lampulo & $16,974,000$ & 900,000 & $4,875,000$ & $22,749,000$ \\
3. & Meuraxa & $7,544,000$ & 400,000 & $4,875,000$ & $12,819,000$ \\
4. & Ulee Kareng & $19,803,000$ & $1,050,000$ & $4,875,000$ & $25,728,000$ \\
\hline
\end{tabular}

Source: Banda Aceh City Health Office in 2017

\section{c. Cost Analysis of Case Tracking to Hospital}

Case tracking to hospital conducted by the Health Office twice a month involved 4 workers with honorarium of IDR 50,000/person. The amount of money spent each month for this activity was IDR 400,000. The payment of honorarium was only for 6 months while cases occurred throughout the year. The annual cost was IDR 4.800.000 while the cost available was only for 6 months (IDR 2.400.000).

\section{e. Analysis of Mobile Dissemination Cost}

Mobile outreach was conducted by Health Promotion Section of the Health Office to only 50 villages, while the total number of villages in the City of Banda Aceh is 90 villages. Although the availability of cost in 2017 was only
IDR 5.100.000, the officers still performed counseling around the whole villages.

\section{f. Treatment Cost Analysis}

The average cost of hospitalization and medication for DHF patients in class 3 was 1,166.660/person/night. In general, patients stayed for 3 nights so the cost amounted to IDR $3,500,000$ for each patient overnight. The number of DHF cases in Banda Aceh City in the first half of 2017 (January June 2017) amounted to 216 people so the total medical expenses became IDR756.000.000. 


\section{Discussion}

\section{Case Description}

\section{a. Case Distribution by Age Group}

Based on age, the incidence of DHF in this study was more prevalent in the age group above 15 years. The high cases of DHF in this age group can be caused by many children that interacted with the environment outdoor, especially during school and other activities. The situation corresponds to Aldstadt's statement ${ }^{7}$ that DHF disease is caused by dengue virus (vir Den) which can affect all age groups especially children, transmitted by Aedes aegypti mosquitoes (Ae. aegypti) as the primary vector and Aedes albopictus (Ae. Albopictus ) as the secondary vector. A different statement was made by Sutaryo ${ }^{8}$ that most (90\%) of DHF patients were children younger than 15 years of age. The situation is because the children under 15 years old are school-age children who have a lot of interaction outside the home. DHF vectors can be found around the house in places where water can be collected, such as used goods, drums, used tins and vase ${ }^{9,10}$.

\section{b. Case Distribution by Sex}

Based on sex, a similar comparison was found between the sexes of both men and women. Population with male gender suffering from DHF counted 39 cases $(51.32 \%)$ and the remaining 37 cases occurred in female gender $(48.8 \%)$. The situation is in accordance with the research of Gurugama et $\mathrm{al}^{11}$ that men and women have the same opportunity to be infected with this disease.

\section{c. Case Distribution by Place of Residence}

Most cases were found in Baiturrahman Health Center with 31 cases $(40.79 \%)$ since its area is the most densely populated area among the other health centers. Densely populated areas are more susceptible to transmission because they are accompanied by high population mobility. Densely populated environments with waterlogging are potential sites for DHF vectors to breed. ${ }^{12}$ Furthermore, Rahman ${ }^{13}$ suggested that the condition of the housing environment is related to the incidence of dengue hemorrhagic fever (DHF). This current study showed there was a relationship between mosquito breeding places and the DHF case.

\section{d. Case Distribution by Case Detection Time}

Based on case detection time, the highest number of cases was found in January as many as 25 cases (32.9\%), followed by February as many as 24 cases (31.6\%) as those two months are in rainy season in the area. The situation is in line with Timmreck ${ }^{12}$ that DHF cases are found in the rainy season. Climate factors affect the number of DHF cases, i.e., relative temperature and humidity during the rainy season supporting the propagation of the DHF vector. ${ }^{14}$ January and February are months with high rainfall so many places are inundated. Similarly, used goods may be filled with water which makes the mosquito breed $^{15,16}$.

\section{Bivariate Analysis of Research Variables}

Good health financing is the one that is sufficient, fairly distributed according to need and utilized according to the allocation. ${ }^{17}$ Inadequate costs with incompatibility mismatch and allocation become one of the causes of unsuccessful health programs. According to $\mathrm{Gani}^{18}$, the availability of adequate cost and proper use in the provision of health services supports the success of a health program. The function of health financing is one of the determinants of health performance. ${ }^{19}$ These functions include mobilizing and channeling or allocating funds in the operation of the health system ${ }^{20}$.

This study showed that insufficient program costs were significantly associated with DHF incidence with a pvalue of 0.005 and OR of 2.49 at $95 \%$ CI between 1.23 and 5.06. The results of the analysis can be interpreted that insufficient cost can increase the number of DHF cases as much as 2.49 times compared to sufficient cost. It thus shows that the allocation of government-sourced funds managed by the health sector has not been effective. Inadequate costs are influenced by the commitment of the local government budget allocation to the infectious disease control program. ${ }^{21}$ Thus, financing is an important control tool for the success of a policy. ${ }^{22}$

Under such conditions, the Health Office should be more careful in drafting guidelines for determining the costs associated with the DHF disease control program. The guidelines contain an overview of each of the activity steps to be implemented in the costing of the control program against DHF disease. The research on DHF cost guidance conducted by Constenla et al. ${ }^{23}$ can provide direction to planners and program managers on the estimates of the economic burden of DHF disease. The information is the basis for submission to the local government about the 
current healthcare funding conditions. This is where we find the role of government in health financing.

In health financing in various countries, almost all role of the government is found. According to the concept of "good governance", one of the government roles besides acting as regulator and implementer of health service also acts as a donor. ${ }^{18,24}$ To obtain government support, it is important to calculate or record in determining the allocation of costs for program activities, setting priorities of intervention activities, improving health system performance and advocating the funders. ${ }^{25}$ Similarly, the control program against DHF disease is expected to receive financial support from the Central Government and Local Government.

The funding of the DHF disease control program in Banda Aceh City is only sourced from the District/City Revenue and Expenditure Budget without additional funds from other parties. The amount of funds that continues to decrease from year to year is not in accordance with the number and types of program activities that must be done up to the health center level, even though the health center has Health Operational Assistance (HOS) funds from the central government intended as an operational cost of preventive and promotive activities at the health center level and its network. The funds are also used for Community Based Health Efforts in accordance with Minimum Service Standards and Millennium Development Goals (MDGs) ${ }^{26}$..

Each PHC has a variety of health programs with various types of diseases in the community while the amount of funds is in a limited number. As a result, the funds are insufficient for each program activity, so that DHF disease control program officers at the health center level cannot rely on HOS funds to achieve program objectives.

The lack of funds for the DHF disease control program in Banda Aceh City shows that the program is not included as a priority program. To obtain such support, more effective advocacy is needed based on precise, clear and detailed financial information as priority setting of regional development becomes the regional authority. To prioritize the work program of the Local Government, the Health Office as a technical unit should be able to convince the stakeholders of the Regional Government that public health service is a very important and urgent matter. The health profile should be able to describe the priority of the program especially the DHF disease control program which has caused pain, unrest and loss in the community. Therefore, the financing of priority programs is one of the important issues in the implementation of the health system in the region ${ }^{21,27}$.

\section{Cost Analysis of DHF Program}

\section{a. Cost Analysis for Each DHF Case}

The magnitude of costs for each DHF case from 2015 to 2017 showed the relationship between program cost reduction and the increase in the number of DHF cases. The number of DHF cases in the first half of 2017 had reached 216 people. Thus, the reduced cost of the program is one of the causes of the high case of DHF in Banda Aceh City. Reduced program costs relates to activities to be undertaken. For that, we need controlling program financing guidelines about DHF disease. These cost guidelines can provide guidance to program planners and managers about the estimated study of the economic burden of DHF disease. The information is the basis for submission to the local government on the current healthcare funding conditions $^{28,29}$.

To obtain government support, it is important to calculate or record in determining the allocation of costs for program activities, prioritization of intervention activities, improvement of health system performance and advocacy to funders. ${ }^{30}$ Similarly, the control program against DHF disease is expected to receive financial support from the Central Government and Local Government. Cost deficiencies are an important note for getting cost allocation especially for prioritized activities with harder efforts and strategies to get the fund. To help limit the funding from the government, it is necessary to mobilize public and private sources of funds ${ }^{31}$.

\section{b. Cost Analysis for Each Selected PHC}

The total cost for each PHC is provided by the Municipal Health Office of Banda Aceh in accordance with the number of the PHCs. In the four selected PHC areas, the most cost was given to Baiturrahman PHC amounting to IDR 39,630,500 and the lowest cost was given to the Meuraxa PHC for IDR 12,819,000. Details of the amount of the costs are for fogging focus for 2 cycles, epidemiological reserach and abate. The amount of cost for DHF disease control program is widely used for curative activities (fogging) while for preventive activities such as mosquito-nest eradication is very little done. The eradication program is the best way to reduce mosquito populations. In carrying out the activities, community participation is greatly needed ${ }^{32,33}$. 
DHF is one of the environmental-based diseases so it needs a community-based activity in its control effort. Thailand is one of the countries that has managed to control DHF through community-based activities. Research conducted by Suwanbamrung et $\mathrm{al}^{34}$ in southern Thailand shows that activities involving communities can reduce the number of DHF cases. The participation of local communities at various levels is more effective than outside intervention.

\section{c. Cost Analysis of Case Tracking to Hospital}

The availability of costs for case tracking to hospitals conducted by Banda Aceh City Health Office is not inadequate. Tracking cases must be done 2 times a month involving 4 people. However, the payment of honorarium is only for 6 months while cases occur throughout the year. Lack of cost for 6 months is a problem related to program performance. Lack of costs along with mismatches of distribution and allocation is one of the causes of unsuccessful health programs. The availability of sufficient cost and proper use in the provision of health services support the success of a health program ${ }^{18,35}$. Thus, the lack of cost is one of the failure causes of the DHF disease control program in Banda Aceh City.

\section{d. Analysis of Mobile Outreach Costs}

The availability of mobile outreach/counseling costs in 2017 was IDR 5.100.000. for 50 villages while the number of villages in Banda Aceh City area is 90 villages. Despite the limited costs, the Health Promotion Section keeps conducting such counseling to the entire village. This situation is certainly not in accordance with the designation of each village. Such non-conformity is one of the causes of the failure of the DHF disease control program in Banda Aceh City.

\section{e. Treatment Cost Analysis}

The amount of cost burden for the treatment of dengue hemorrhagic disease (DHF) depends on the severity of the illness. If you have to get treatment to stay in the hospital, the average cost is IDR 1.166.667. The amount of the fee includes the cost of room rent, laboratory examination and medication. In general, patients with hospitalization within $\quad 3$ nights will spend a cost of IDR 3.500.000. The total cost of DHF treatment for 216 cases with average patient stay for 3 nights is IDR
$756,000,000$. The amount should be spent within half a year. In addition, if the number of cases continues to increase, the cost of treatment will then increase as well. Expenditure becomes greater because each case found must be done 2 fogging cycles with the cost of IDR 943,000 and epidemiological research cost of IDR 50,000 for each case. The total cost of fogging and epidemiological research for 216 cases is IDR 203,688,000 and IDR 10.800.000, respectively, so that the amount of treatment (curative) was IDR 970.488.000.

Based on research conducted in Colombia, cost calculations include costs for treatment and losses caused by a disease. ${ }^{37}$ The large expenditure of health expenses for treatment is often not realized by the Regional Government and the people representatives. For that, the Health Office needs to explain to stakeholders that the cost of treatment (curative) is much greater than the cost of activities for prevention (preventive). Thus, the stakeholders who in fact are not experts in the field of health can better understand the health problems that are happening in the community.

\section{CONCLUSION}

The financing of DHF disease control program is closely related to the number of DHF cases in Banda Aceh City. Inadequate financing for DHF control program in this city could increase the DHF cases by 2.49 times compared with sufficient financing. Based on the number of cases, the most expensed program costs are for fogging focus activities, while the cost for treatment is not included in program planning. In addition, the cost for treatment (curative) is also greater than that for prevention (preventive).

\section{RECOMMENDATION}

Since not having sufficient costs can increase the number of DHF cases in Banda Aceh City, Banda Aceh City Health Office needs to make more effective advocacy with stakeholders to get support to make DHF disease control program a priority program for increased support of funds. For that, the stakeholders need to make a special meeting with related parties in order to formulate a clear and definite commitment to the effort of controlling DHF disease in Banda Aceh City. 


\section{REFERENCE}

1. WHO. (2009). Dengue/Dengue Haemorrhagic Fever. Fact Sheet, Period Marc 2009. Available from: $<$ http://www.who.

2. WHO. (2017). World health statistics 2017: monitoring health for the SDGs, Sustainable Development. Available fromhttp://www.who.int/gho/publications/world healt h_statistics/2017/en/

3. Departemen Kesehatan RI. (2009).Profil Kesehatan Indonesia 2008. Pusat Data dan Informasi Kesehatan, Jakarta.

4. Kementerian Kesehatan RI. (2013). Ditjen PP dan PL. Kementrian Kesehatan Republik Indonesia.

5. Kementerian Kesehatan RI.(2017). Ditjen PP dan PL. Kementrian Kesehatan Republik Indonesia.

6. Dinas Kesehatan Kota Banda Aceh. (2017).Profil Dinas Kesehatan Kota Banda Aceh 2017.

7. Aldstadt, J., Koenraadt C. J. M., Fansiri, T., Kijchalao, U., Richardson, J., Jones, J. W. \& Scott, T. W. (2011). Ecological Modeling of Aedes aegypti (L) Pupal Production in Rural Kamphaeng Phet, Thailand. PLoS Medicine. 5(1).

8. Sutaryo. (2004). Dengue. Medika. Fakultas Kedokteran Universitas Gadjah Mada. Yogyakarta.

9. Harrington, L.C., Scott, T.W., Lerdthusnee, K., Coleman, R.C.,Costero, A., Clark, G.G., Jones, J.J., Kitthawee, S., Kittayapong,P., Sithiprasasna, R., Edman, J.D., 2005. Dispersal of the denguevector Aedes aegypti within and between rural communities, part 1.Am. J. Trop. Med. Hyg. 72, 209-220.

10. Murugan, K., Hwang, J.S., Kovendan, K., Prasanna Kumar, K.,Vasugi, C., Naresh Kumar, A., 2011. Use of plant products and copepods for control of the dengue vector, Aedes aegypti. Hydrobiologia. 666, 331-338.

11. Gurugama, P., Garg, P., Perera, J., Wijewickram,A. \& Seneviratne, S. L. (2010). Dengue Viral Infections. Indian J. Dermatol. 55 (1): 68-78.

12. Widyawati., Nitya I., Syaukat S., Tambunan, R. P. \& Soesilo, T. E. (2011). Penggunaan Sistem Informasi Geografis Efektif Memprediksi Potensi Demam Berdarah di Kelurahan Endemik. Jurnal Makara Kesehatan. 15 (1): 21 - 30.

13. Rahman. D. A. (2012). Hubungan Kondisi Lingkungan Rumah dan Praktik3M dengan Kejadian Demam Berdarah Dengue (DBD) di WilayahKerja Puskesmas Blora Kabupaten Blora. UJPH. 1 (2).
14. Thu,H.M., K. Lowry,T.T.Myint,et al. 2004. Myanmar Dengue Outbreak Associated with Displacement of Serotype 2,3, and 4 by Dengue 1.Emerg. Infection. 10:593-597

15. WHO. (2003). Prevention and control of dengue and dengue haemorrhagic fever. New Delhi India:WHO Regional Publication SEARO. Available from:http://www.searo.who.int.

16. Timmreck, T. C. (2005). An Introduction of Epidemiology. Penerbit Buku Kedokteran EGC. Jakarta.

17. Azwar, A. (1996). Pengantar Administrasi Kesehatan. Edisi Ke-3. Jakarta: Binarupa Aksara.

18. Gani, A. (2009). Pedoman dan Modul Pelatihan District Health Account (DHA) untuk Tingkat Kabupaten dan Kota. Jakarta: Pusat Pembiayaan dan Jaminan Kesehatan Depkes RI.

19. WHO. (2000) World Health Report. World Health Organization. Available from: http://www.who.int.

20. Eliya, R. (2008). Strengthening Health Financing in Partner Developing Countries. Available from: www.jcie.org/researchpdf/.

21. Supardi, S. \& Mahendradhata, Y. (2005). Desentralisasi Kesehatan dan Pelaksanaan Program Pemberantasan Penyakit Menular dalam ; Trisnantoro, Desentralisasi Kesehatan di Indonesia dan Perubahan Fungsi Pemerintah: 2001 - 1003. Gadjah Mada University Press.

22. Trisnantoro, L. (2010). Sistem Kesehatan dan Reformasi. Makalah Kuliah Health ReformKMPK 2010. IKM UGM.

23. Constenla, D., Armien, B., Arredondo, J., Carabali, M.,Carrasquilla, G., Castro, R., ... Martelli, C.T. (2015). Costing Dengue Fever Cases and Outbreak; Recommendations from a Costing Dengue Working Group in the Americas. Value Health Reg Issues. 8c.: $80-91$.

24. Trisnantoro, L. (2006). Perubahan Fungsi Pemerintah dalam Sektor Kesehatan dalam Perencanaan dan Penganggaran untuk Investasi Kesehatan Kabupaten dan Kota. Editor: Laksono Trisnantoro. Yogyakarta: Gadjah Mada University Press.

25. Murti. B. (2006). Menghitung Biaya Intervensi Kesehatan dalam Perencanaan dan Penganggaran untuk Investasi Kesehatan Kabupaten dan Kota. Editor: Laksono Trisnantoro. Yogyakarta: Gadjah Mada University Press. 
26. Kementerian Kesehatan RI. (2011b). Petunjuk Teknis BOK. Jakarta: Departemen Kesehatan Republik Indonesia.

27. Schieber, G., Baeza C., Kress D. \& Maier M. (2006). Financing Health Systems in the 21st Century in Disease Control Priorities in Devoloping Countries, 2nd ed. Editor: Dean T. Jamison, et al. England: Oxford University Press and The World Bank.

28. Heruela, R. P. \& Cempron - Cuamora, J. T. (2015). National Dengue Prevention and Control Program: A Policy Impact Analysis. $M J N$. 6. (2): 40 - 48.

29. Packierisamy, P . R., Chiu-Wan Ng., Dahlui, M., Inbaraj, J., Balan, V. K., Halasa, Y. A . \& Shepard, D. S.(2015). Cost of Dengue Vector Control Activities in Malaysia. Am. J. Trop. Med. 93 (5): 80 - 91.

30. Murti. B. (2006). Menghitung Biaya Intervensi Kesehatan dalam Perencanaan dan Penganggaran untuk Investasi Kesehatan Kabupaten dan Kota. Editor: Laksono Trisnantoro. Yogyakarta: Gadjah Mada University Press.

31. Hendrartini, J. \& Mukti, A. G. (2005). Perubahan dalam Pembiayaan: Desentralisasi, Pola Tarif dan Jaminan Kesehatan Sosial dalam: Trisnantoro, Desentralisasi Kesehatan di Indonesia dan Perubahan Fungsi Pemerintah: 2001 - 2003. Gadjah Mada University Press.

32. Kementerian Kesehatan RI. (2015). Ditjen PP dan PL. Kementrian Kesehatan Republik Indonesia.

33. Hayani A., Erlan, A.\&Yunus W. (2006). The Influence Of UKS (School Health Program) Teacher's Training On Eradication of Breeding Places of Dengue Haemoraghic Fever (DHF) Effectivity In Palu Municipality, Central Sulawesi Province.The Indonesian Journal of Health Ecology. 5(1).

34. Suwanbamrung, C., Nukan, N., Sripon, S, Somrongthong, R. \&Singchagchai, P.(2010). Community capacity for sustainable community-based dengue prevention and control: study of a sub-district in Southern Thailand. Asian . Pac. J. Trop. Med: $215-$ 219.

35. WHO. (2011). National Health Account. Available from:http://www.who.int.

36. Castaneda-Orjuela, C., Diaz, H., Alvis-Guzman, N., Olarte, A., Rodriguez, H., Camargo, G. \& la HozRestrepo, F. D .(2012). Burden of Disease and Economic Impact of Dengue and Severe Dengue inColombia, 2011. Value Health Reg. Issues. 1:123 128.
37. Rodríguez, R. C., Gabriel Carrasquilla, G., Porras, A.,Galera-Gelvez, K., Yescas, J. G.L. \&RuedaGallardo, J. A.(2016). The Burden of Dengue and the Financial Cost to Colombia, 2010-2012. Am. J. Trop. Med. Hyg., 94(5): 1065-1072. 